\title{
Bile salt secretion in cirrhosis of the liver
}

\author{
LESLIE A. TURNBERG ${ }^{1}$ AND GORDON GRAHAME 2 \\ From the Department of Medicine, Royal Free Hospital, London
}

SUMMARY Secretion of bile salts into the duodenum was studied in eight normal subjects, in 10 patients with cirrhosis, and in two cholecystectomized subjects. Duodenal juice was $\vec{\varphi}$ aspirated continuously through a double-lumen tube during an unstimulated period, after $\stackrel{ }{.}$ an intravenous injection of pancreozymin/cholecystokinin, and during a continuous intravenous infusion of secretin given at a rate of 3 units per kilogram body weight per hour. Precautions were taken to try to ensure quantitative recovery during the studies, and recovery of an infused nonabsorbable marker was greater than $80 \%$ in all subjects.

Secretin induced a flow of a greater volume of juice in the cirrhotic patients than in the $\overrightarrow{\vec{P}}$ normal group ( 49 to $57 \mathrm{ml}$ per 10 minutes compared with 28 to $49 \mathrm{ml}$ per 10 minutes). This $\Xi$ change may have resulted from a higher effective dose of secretin if it is assumed that the cirrhotic liver fails to catabolize secretin.

The bile acid response to pancreozymin/cholecystokinin followed by secretin in the cirrhotic subjects resembled that seen in patients after cholecystectomy in whom pancreozymin/ cholecystokinin induces only a slight increase in bile salt output but in whom the output of bile salts during rest and secretin stimulation is markedly greater than normal. This response in cirrhosis is probably best interpreted as due to impaired function of the gallbladder. The $\mathrm{O}$ total amount of bile salt liberated over the two hours of the test in the cirrhotic patients was $\rightarrow$ similar to normal The concentration of bile salt after pancreozymin/cholecystokinin was less than in normal subjects, but similar to that in cholecystectomized patients. It is unlikely therefore that deficient output or concentration of bile salt can be held responsible for steator- $N$ rhea in cirrhosis.

There was a marked decrease in the deoxycholate conjugates and a reduction in the glycine:承 taurine ratio in the bile of cirrhotic patients. The former change may reflect a change in bacterial flora and the latter a defect in hepatic conjugating mechanisms. 


\begin{tabular}{|c|c|c|c|c|c|c|c|c|c|c|c|}
\hline $\begin{array}{l}\text { Case } \\
\text { No. }\end{array}$ & Subject & Sex & Age & Diagnosis & $\begin{array}{l}\text { Compli- } \\
\text { cation }\end{array}$ & Therapy & $\begin{array}{l}\text { Serum } \\
\text { Bilirubin } \\
(\mathrm{mg} / 100 \mathrm{ml})\end{array}$ & $\begin{array}{l}\text { Serum } \\
\text { Albumin } \\
(\mathrm{g} / 100 \mathrm{ml})\end{array}$ & $\begin{array}{l}\text { Alkaline } \\
\text { Phosphatase } \\
(\text { KA units } \\
100 \mathrm{ml})\end{array}$ & $\begin{array}{c}S G P T \\
e(I U / m l)\end{array}$ & $\begin{array}{l}\text { Faecal } \\
\text { Fat } \\
(\mathrm{g} / \text { day })\end{array}$ \\
\hline 1 & W.K. & 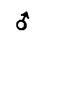 & 69 & $\begin{array}{l}\text { Cryptogenic } \\
\text { cirrhosis }\end{array}$ & $\begin{array}{l}\text { Porta- } \\
\text { systemic } \\
\text { encepha- } \\
\text { lopathy }\end{array}$ & Neomycin & $1 \cdot 2$ & $3 \cdot 5$ & 12 & 7 & - \\
\hline 2 & P.C. & q & 59 & $\begin{array}{l}\text { Cryptogenic } \\
\text { cirrhosis }\end{array}$ & $\begin{array}{l}\text { Porta- } \\
\text { systemic } \\
\text { encepha- } \\
\text { lopathy }\end{array}$ & Neomycin & $1 \cdot 3$ & $3 \cdot 1$ & 13 & 13 & - \\
\hline 3 & E.C. & $\sigma$ & 53 & $\begin{array}{l}\text { Cryptogenic } \\
\text { cirrhosis }\end{array}$ & - & - & $7 \cdot 4$ & $3 \cdot 0$ & 20 & 31 & $15 \cdot 3$ \\
\hline 4 & F.B. & $\sigma^{\alpha}$ & 53 & $\begin{array}{l}\text { Chronic active } \\
\text { hepatitis + } \\
\text { cirrhosis }\end{array}$ & - & - & $5 \cdot 2$ & $3 \cdot 5$ & 52 & 500 & $7 \cdot 7$ \\
\hline 5 & E.R. & $q$ & 57 & $\begin{array}{l}\text { Cryptogenic } \\
\text { cirrhosis }\end{array}$ & - & - & $3 \cdot 5$ & $3 \cdot 1$ & 20 & 180 & 3 \\
\hline 6 & D.S. & q & 62 & $\begin{array}{l}\text { Cryptogenic } \\
\text { cirrhosis }\end{array}$ & - & - & $1 \cdot 8$ & $2 \cdot 4$ & 18 & 31 & 8 \\
\hline 7 & C.T. & 0 & 42 & $\begin{array}{l}\text { Cirrhosis + } \\
\text { ulcerative } \\
\text { colitis }\end{array}$ & - & - & $3 \cdot 0$ & $3 \cdot 3$ & 68 & 42 & 5 \\
\hline 8 & S.S. & $\sigma^{*}$ & 58 & $\begin{array}{l}\text { Alcoholic } \\
\text { cirrhosis }\end{array}$ & Ascites & $\begin{array}{l}\text { Furose- } \\
\text { mide }\end{array}$ & $2 \cdot 6$ & $4 \cdot 3$ & 26 & 62 & 2 \\
\hline 9 & D.T. & ㅇ & 41 & $\begin{array}{l}\text { Chronic active } \\
\text { hepatitis + } \\
\text { cirrhosis }\end{array}$ & - & - & $10 \cdot 0$ & $3 \cdot 7$ & 32 & 83 & 7 \\
\hline 10 & V.H. & ㅇ & 38 & $\begin{array}{l}\text { Cryptogenic } \\
\text { cirrhosis }\end{array}$ & - & - & $>0.5$ & $4 \cdot 2$ & 120 & 44 & - \\
\hline
\end{tabular}

Table I Clinical details of the patients with cirrhosis

While bile salt production is one of the major functions of the liver, surprisingly little is known of changes in this function which occur in hepatic disease. It has been suggested that the high faecal fat excretion often found in patients with cirrhosis is due to alteration in bile salts (Gross, Comfort, Wollaeger, and Power, 1950a), but, although some information is available on qualitative changes (Ekdahl, 1958; Sandberg, Sjövall, Sjövall, and Turner, 1965; Carey, 1958; Sjövall, 1960) and on turnover rates and size of the bile salt pool (Blum and Spritz, 1966) in this disease, no quantitative estimations have been made of bile salt production and liberation into the duodenum. The investigations reported here were performed in a search for abnormalities in biliary secretion of bile salts in patients with cirrhosis.

\section{Patients Studied}

The following groups of patients were studied.

(a) Eight control subjects without hepatic disease and in hospital for investigation of nonhepatic symptoms, usually obscure upper abdominal pain. Routine tests of liver function were normal. The age range was 26 to 58 years.

(b) Two patients with normal liver function who had had a cholecystectomy two years and 20 years before respectively. (c) Ten subjects with hepatocellular disease, of whom nine had cryptogenic, macronodular cirrhosis, and one had alcoholic micronodular cirrhosis. The diagnosis was made on clinical grounds and biochemical investigation and was confirmed on liver biopsy in all cases. Two patients with cryptogenic cirrhosis (cases 1 and 2) had a large collateral circulation and symptoms of porta-systemic encephalopathy. One patient (case 8) had ascites and was receiving diuretic therapy. The clinical details of these patients are shown in Table I.

\section{Procedure}

Patients were fasted from $6.00 \mathrm{pm}$ and intubated at 8.00 to 9.00 am the following morning. A doublelumen Portex PVC tube, $4.2 \mathrm{~mm}$ in diametei with a rubber bag containing $2 \mathrm{ml}$ of mercury tied to one end, was swallowed and allowed to pass through the pylorus until the end reached a point just beyond the junction of the second and third parts of the duodenum and its position confirmed radiologically. Juice was aspirated by continuous suction from the duodenum through six $2 \mathrm{~mm}$ diameter holes sited in a $6 \mathrm{~cm}$ segment of one lumen of the tube lying adjacent to the ampulla of Vater. An 'air-bleed' PVC tube, $2 \mathrm{~mm}$ diameter, inserted into the most 
distal hole of the duodenal tube and open to the atmosphere at the other end, prevented the development of too great a negative pressure during suction and facilitated collection. Gastric juice was aspirated with intermittent hand suction by syringe through six $2 \mathrm{~mm}$ diameter holes in the second lumen of the tube sited $16 \mathrm{~cm}$ from the tip. During aspiration a $0.5 \%$ solution of the non-absorbable marker, polyethylene glycol (PEG), was infused at a rate of $1.4 \mathrm{ml}$ per minute through a separate, loosely attached, tube, $2 \mathrm{~mm}$ diameter, opening $2 \mathrm{~cm}$ above the duodenal aspiration site. Recovery of bile was calculated from the proportion of the infused PEG recovered from the duodenum. Recovery estimated in this way was greater than $80 \%$ in all cases.

As secretion of bile and pancreatic juice is minimal during fasting, flow was stimulated by an intravenous infusion of secretin ${ }^{1}$. To reduce the likelihood of the gallbladder spontaneously contracting during the test, which would cause an erroneously high apparent production of bile during any one collection period, an intravenous injection of pancreozymin/cholecystokinin ${ }^{1}$ was given at the start of each study to promote a predictable contraction of the gallbladder. Gallbladder function could also be assessed by this procedure.

Duodenal juice was collected during separate consecutive 10-minute periods, and after three resting periods an intravenous injection of pancreozymin/cholecystokinin, 100 units in 20 $\mathrm{ml}$ water, was given slowly during five minutes. A further three 10-minute collections were made and then an intravenous infusion of secretin in a dose of 3 units per kilogram body weight per hour was started. The infusion was continued for 60 or 70 minutes while further collections were made. In four studies an attempt was made to induce a second contraction of the gallbladder at the end of the secretin infusion by injecting 4 $\mathrm{ml}$ of $10 \%$ magnesium sulphate into the duodenum via the tube. In none was there a response to suggest a further contraction of the gallbladder. In one study in a normal subject secretin was infused first, after the resting period, and the pancreozymin/cholecystokinin injected after the secretin. Specimens were immediately refrigerated after each collection period and kept frozen until processed.

Bile for estimating bile salt was extracted as follows. Five $\mathrm{ml}$ of juice was extracted with 5 volumes of redistilled methanol and warmed to $37^{\circ} \mathrm{C}$ for five minutes. The precipitated proteins were removed by centrifugation and the precipitate was washed twice with 1 volume of methanol. The pooled methanolic extracts were evaporated to dryness and the residue extracted three times with petroleum ether $\left(40-60^{\circ}\right)$ to remove lipids. The residue was finally taken up in $2 \mathrm{ml}$ of ethanol.

Total bile salts were measured by a modification (Turnberg and Anthony-Mote, 1969) of the enzyme method of Iwata and Yamasaki

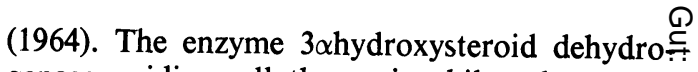
genase oxidizes all the major bile salts at the $3 \alpha \mathrm{OH}$ group and liberates one mole of $\mathrm{H}^{+}$from? each mole of bile salt. The $\mathrm{H}^{+}$produced may be measured by the spectrophotometric determina $\overline{\bar{n}}$. tion of NADH formed from NAD.

Of bile extract diluted between 1 and 100 times in ethanol according to the bile salt concentration, $0.1 \mathrm{ml}$ was mixed with $0.6 \mathrm{ml}$ of $0.1 \mathrm{M}$ pyro- $-\overrightarrow{0}$ phosphate buffer, $p \mathrm{H} 10.8,0.5 \mathrm{ml}$ of $0.005 \mathrm{M}-$ $\mathrm{NAD}$, and $0.3 \mathrm{ml}$ of a solution of the enzyme 3 hydroxysteroid dehydrogenase prepared fromo the freeze-dried organism Pseudomonas testo $=$ steronii $^{2}$ containing $10 \mathrm{mg}$ of the unpurified $\overrightarrow{-}$ material per millilitre. After 40 minutes' incu- N bation at $26^{\circ} \mathrm{C}$ the amount of NADH produced was measured at $340 \mathrm{~m} \mu$ in $1 \mathrm{~cm}$ microcells in ao Zeiss spectrophotometer and the amount of bile salt calculated from the formula $\frac{A \times 1.5}{6.22} \frac{\mathbb{O}}{C}$ $\mu$ moles, where $\mathrm{A}$ is the measured extinction of $\mathrm{NADH}$ at $340 \mathrm{~m} \mu$ and $6.22 \times 10^{6}$ is its molar extinction.

Bile salts were separated by thin-layer chromatography in the solvent systems I and II of Hofmann (1962) before and after alkali hydro-s lysis at $110^{\circ} \mathrm{C}$ for 18 hours. After detection by spraying with iodine, bile salt spots were marked $\frac{\varnothing}{\varnothing}$ out, iodine was removed by sublimation, and $\propto$ the spots scraped off and agitated with $1.4 \mathrm{ml} \overrightarrow{\overrightarrow{0}}$ pyrophosphate buffer. After centrifugation, 0.73 $\mathrm{ml}$ of supernatant was used in the further enzymatic determination of each bile salt (Turnberg and Anthony-Mote, 1969).

Polyethylene glycol was measured by the turbidometric method of Hyden (1956), and 3 . faecal fat by the method of van de Kamer, ten Bokkel Huinink, and Weyers (1949).

\section{Results}

The volume of duodenal juice recovered was 0 higher in the cirrhotic group than in the normal $\mathbb{N}^{N}$ subjects in all but one of the 10-minute collection 0 periods(Figure 1). The difference between the mean 0

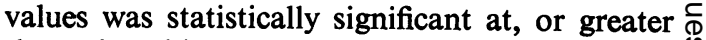
than, the $5 \%$ level in the second resting period, $\stackrel{?}{?}$ the second post-pancreozymin period, and in 7 most of the periods during secretin infusion. The mean volumes during secretin stimulation $\stackrel{\square}{\overparen{D}}$ were 28 to $49 \mathrm{ml}$ per 10 minutes in the normal $\stackrel{\mathbb{\Omega}}{\stackrel{\circ}{\circ}}$ group and 49 to 57 per 10 minutes in the cirrhotic patients. The peak output after pancreozymin occurred promptly during the first 10 minutes in the normal group but was delayed until the second 10 minutes in the cirrhotic patients (Fig. 1), although the mean peak volumes were similar

${ }^{1}$ Boots Pure Drug Co., Nottingham, England.

'Obtained from Worthington Biochemical Co. Freehold, New Jersey. 


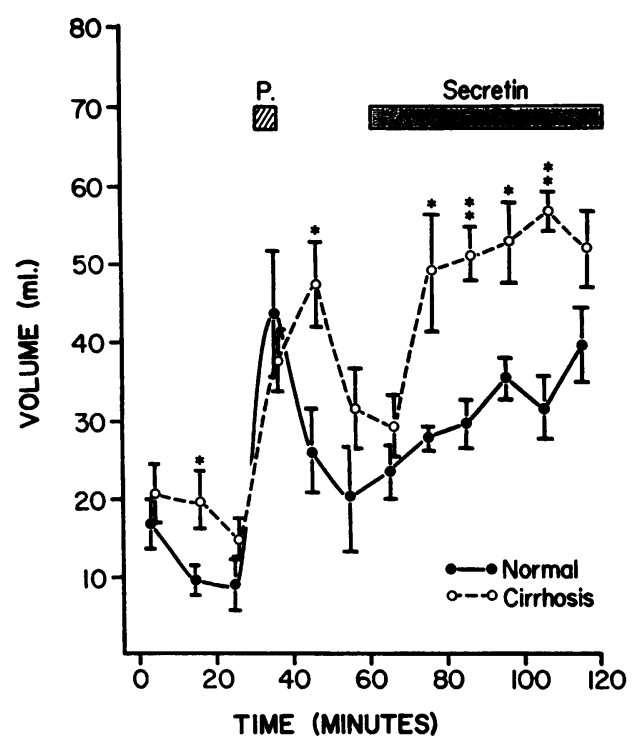

Fig. 1 Mean volume output for each 10-minute period is shown $\pm 1 S E$ for the eight normal and 10 cirrhotic patients. In this and subsequent figures $P$ indicates cholecystokinin/pancreozymin 100 units given over five minutes and the secretin was infused at a rate of 3 units $/ \mathrm{kg} /$ hour. The statistically significant differences between the mean values are indicated here, and in Figs 2 and 4, by the symbols: $*=\mathrm{P}<0.05 ; *=\mathbf{P}<0.01$, and, in some figures $\Delta=\mathbf{P}<0 \cdot 1$.

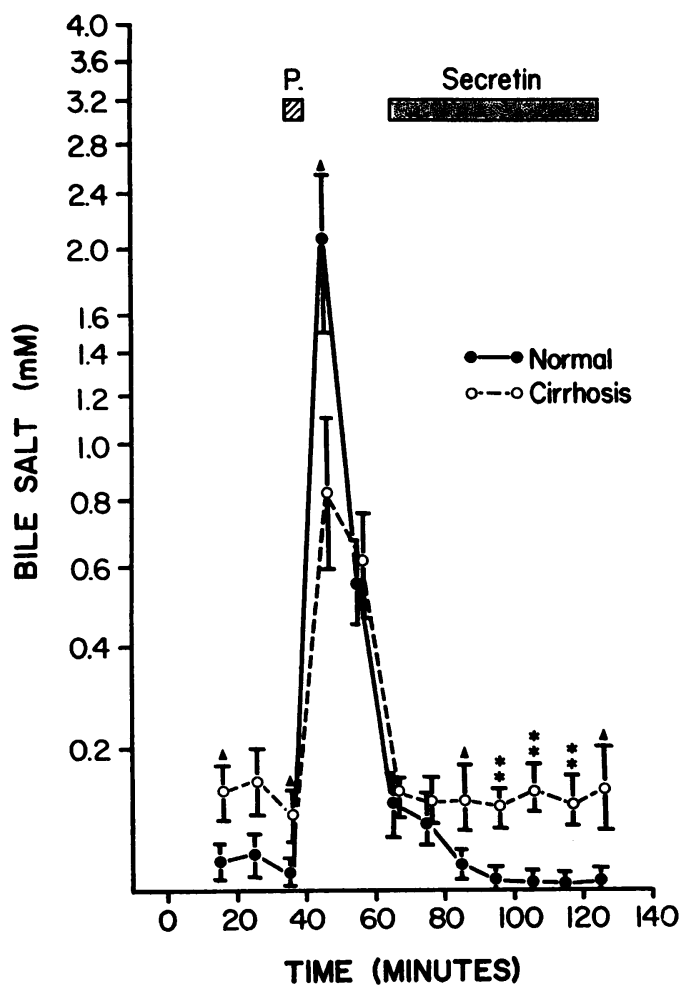

at $44 \mathrm{ml}$ and $47 \mathrm{ml}$ per 10 minutes for normal and cirrhotic groups, respectively.

The volumes of juice obtained in one of the cholecystectomized patients in response to secretin was greater than in the normal group (values of 60 to $68 \mathrm{ml}$ per 10 minutes compared with 35 $\mathrm{ml}$ per 10 minutes, respectively) but in the other the volumes obtained were similar to normal (33 to $40 \mathrm{ml}$ per 10 minutes). It is interesting to note that the volume of juice produced in response to pancreozymin/cholecystokinin in both subjects was only slightly less than that in the normal group (peak volumes 40 and $33 \mathrm{ml}$ per 10 minutes) despite the absence of a gallbladder. The appearance of the juice was, however, clearly different, being much paler and less bile stained in the cholecystectomized patients.

The mean total outputs of bile salts (Fig. 2) in the normal group during the resting periods were 15 to $34 \mu$ moles per 10 minutes. After gallbladder contraction in response to pancreozy$\mathrm{min}$ /cholecystokinin the heavily bile-stained juice contained a mean of $2,050 \mu$ moles bile salt in the first 10 minutes and a total of $2,695 \mu$ moles for the 30-minute period after injection. The range in the first 10 minutes for this group was 800 to $4,150 \mu$ moles, those subjects with the lower outputs tending to have higher outputs in the second and third 10-minute periods after injection. After secretin the juice produced was almost colourless and bile salt outputs were low, mean values being 7 to $12 \mu$ moles per 10 minutes (Figure 2).

In the cirrhotic group the mean resting outputs of bile salts were higher than in any of the normal subjects, ranging from 98 to $140 \mu$ moles per 10 minutes, but the difference was not statistically significant $(0.05<P<0.1)$. The mean output in the first 10 minutes after pancreozymin/ cholecystokinin was $830 \mu$ moles, which is less than the normal mean but not significantly so $(0.05<\mathrm{P}<0.1)$. The mean total output for the 30 minutes after pancreozymin/cholecystokinin was $1,573 \mu$ moles compared with the normal of 2,695 $(\mathrm{P}<0 \cdot 1)$. During the secretin infusion, outputs were significantly higher than normal, mean values ranging from 105 to $128 \mu$ moles; that is, approximately 10 times greater than normal $(\mathrm{P}<0.01)$ (Figure 2). Mean total values for bile salt output for each part of the study are shown for each group in Table II. It is noteworthy that despite the different responses to both pancreozymin/cholecystokinin and secretin of the normal and cirrhotic groups, the total outputs for the whole two hours of the test are very similar in these two groups at 2,930 and

Fig. 2 Mean values for bile salt output in m.moles $\pm 1 S E$ in the normal and cirrhotic groups. Note that the vertical axis in this and the subsequent figures is logarithmic for convenience in presentation of the wide range of response to pancreozymin/cholecysstokinin and to secretin. 


\begin{tabular}{lccc}
\hline & \multicolumn{3}{l}{ Bile Salt Output ( $\mu$ moles) } \\
\cline { 2 - 4 } & Normal & $\begin{array}{l}\text { Cholecys- } \\
\text { tectomy }\end{array}$ & Cirrhosis \\
& $(8)$ & $(2)$ & $(10)$ \\
\hline Resting 30 minutes & 96 & 465 & 371 \\
After pancreozymin & & 507 & 1,573 \\
30 minutes & 2,695 & 980 & 688 \\
Secretin 60 minutes & 141 & 1,952 & 2,632 \\
Total & 2,930 & & \\
\hline
\end{tabular}

Table II Mean total bile salt outputs for each period of the test

$2,632 \mu$ moles, respectively. In one normal subject secretin was infused first for 60 minutes before the injection of pancreozymin/cholecystokinin to compare the secretin response before and after pancreozymin/cholecystokinin. The bile salt output in this subject in response to secretin was similar to that in subjects to whom pancreozymin/cholecystokin had been given first (Figure 3).

Bile salt concentration patterns were also different in the two groups. Higher concentrations were found in the resting period and during secretin infusion in the cirrhotic group, while the concentration after gallbladder contraction was significantly lower than in the control subjects (Figure 4). The mean maximum concentration after pancreozymin/cholecystokinin in the normal group was $4,447 \mu$ moles per $100 \mathrm{ml}$ compared with $1,939 \mu$ moles per $100 \mathrm{ml}$ in the cirrhotic patients $(P<0.01)$. Mean concentrations during secretin ranged from 19 to $34 \mu$ moles per $100 \mathrm{ml}$ in the normal group and from 184 to $243 \mu$ moles per $100 \mathrm{ml}$ in the cirrhotic patients, $P$ values ranging from $<0.01$ to $<0.1$.

The bile salt output pattern for the two cholecystectomized patients is shown in Figure 5. The bile salt response to pancreozymin/cholecystokinin is clearly less than normal, as might be expected in the absence of a gallbladder. The resting output and the output during secretin infusion are similar to each other and both were greater than in the normal controls, particularly during secretin, when normal outputs were very low.

There are several points of similarity between the results obtained in the cirrhotic and in the cholecystectomized patients. The bile salt response to pancreozymin/cholecystokinin was delayed and impaired in the cirrhotic and reduced in the cholecystectomized patients. The secretin response included an increased output and concentration of bile salts in both the cirrhotic and cholecystectomized groups compared with normals. The appearance of the juice after secretin was similar in these two groups and clearly contained bile pigment whereas in the normal group secretin-stimulated juice was almost colourless.

In each subject the specimens of duodenal juice with the greatest concentrations of bile salts

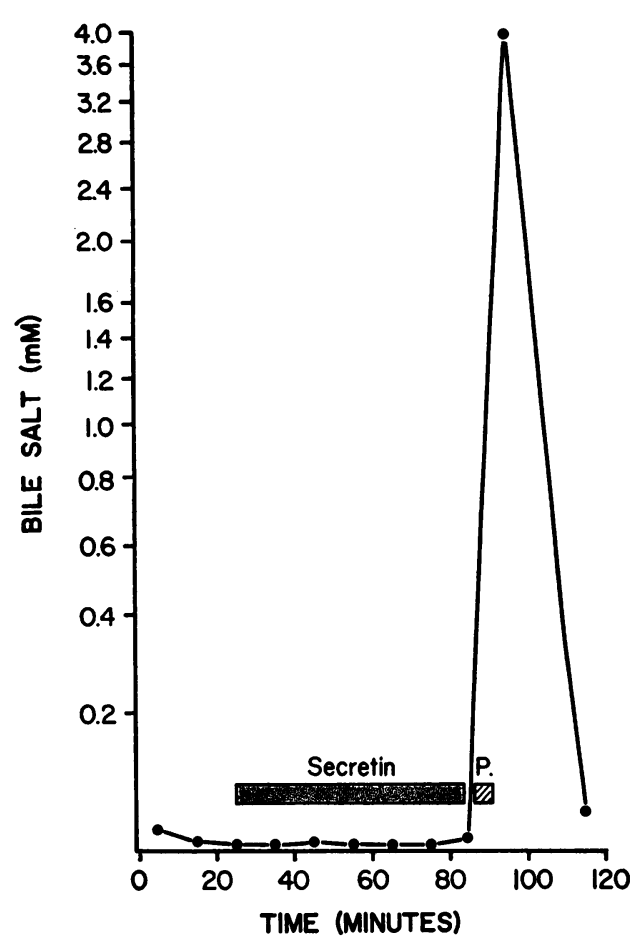

Fig. 3 Bile salt output in one normal subject in whom secretin was infused first and pancreozymin/ cholecystokinin was given second.

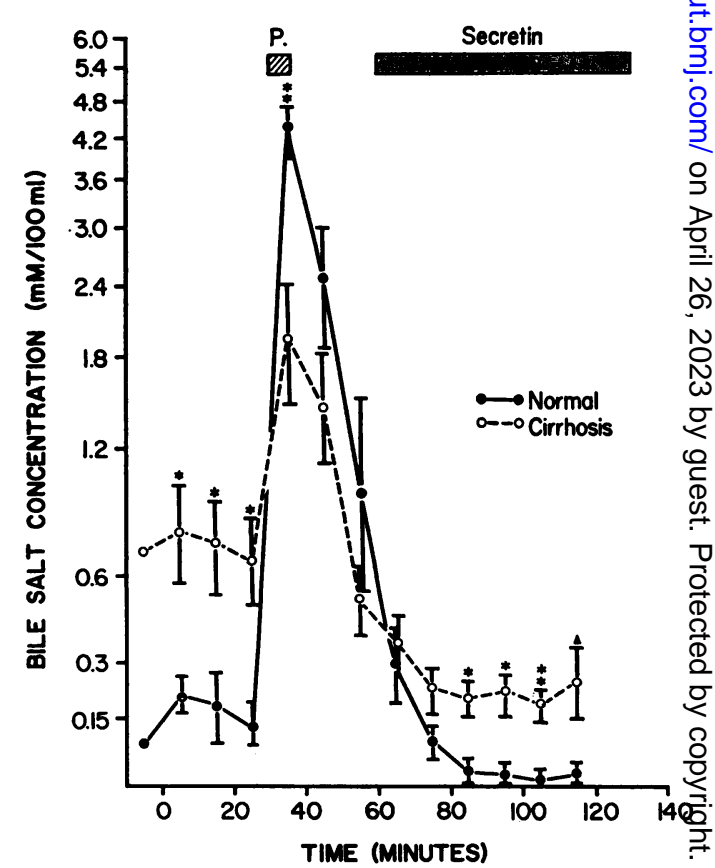

Fig. 4 Mean values for bile salt concentration m.moles/100 ml \pm 1 SE for each 10-minute period in the normal and cirrhotic groups. 


\begin{tabular}{|c|c|c|}
\hline & \multicolumn{2}{|c|}{ Bile Salt Ratio (mean values) } \\
\hline & Normal & Cirrhosis \\
\hline Glycine/taurine & $75: 25$ & 48:52 \\
\hline Trihydroxy/dihydroxy & $41: 59$ & $37: 63$ \\
\hline $\begin{array}{l}\text { Chenodeoxy/ } \\
\text { deoxycholic }\end{array}$ & $64: 36$ & $95: 5$ \\
\hline
\end{tabular}

Table III Bile salt ratios for the normal and cirrhotic groups.

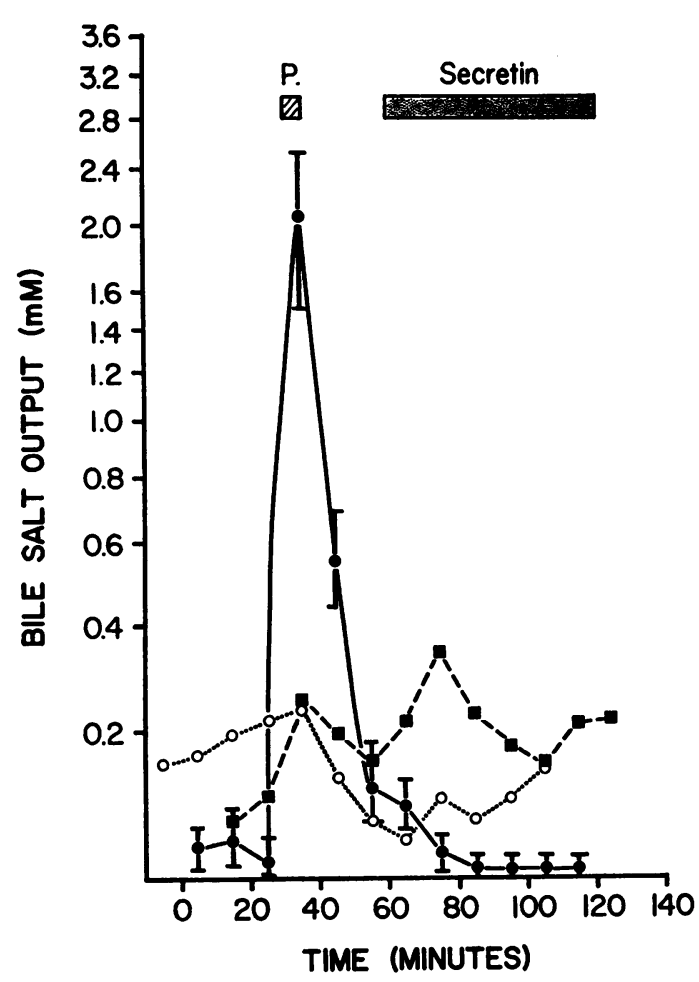

Fig. 5 Mean value for bile salt output $\pm 1 S E$ in the normal group (complete line) and the output in the two cholecystectomized subjects (incomplete lines).

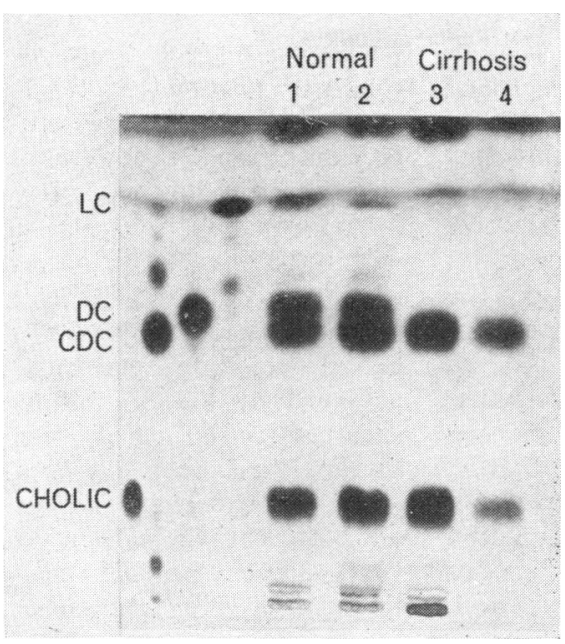

were chromatographed on silica gel thin layers, before and after alkali hydrolysis, as described in the Methods section and individual bile salts were estimated. In the unhydrolysed specimens there were no significant concentrations of deconjugated bile salts or lithocholic acid or its conjugates in any subject.

Estimates of the amounts of bile salts conjugated with taurine and glycine showed the glycine : taurine ratio to be $3: 1$ in the normal group while in the cirrhotic patients the ratio was changed to $1: 1$ and in some subjects was actually reversed (Table III). The increase in the proportion of taurine conjugates was most marked in the patients with the most active hepatocellular disease, as judged clinically and biochemically.

Ratios of the trihydroxy to dihydroxy bile salts were similar in both groups and were approximately $2: 3$.

As the taurine conjugated forms of chenodeoxy and deoxycholic acid run together as do the glycine conjugates of these salts on thin-layer chromatograms in most solvents, it was necessary to hydrolyse them first to distinguish the two dihydroxy acids. While in the normal group the ratio of chenodeoxy to deoxycholic acid was $6 \cdot 4: 3 \cdot 6$ it was markedly different in the cirrhotic patients. In several of these subjects deoxycholic acid could not be detected (Fig. 6) and in others it was present in very small amounts. An average ratio of 19:1 was obtained for chenodeoxy to deoxycholic acid (Table III).

\section{Discussion}

In any study of biliary flow in human subjects, several difficulties arise both in experimental method and in interpretation of results. Inadequate recovery of bile from the duodenum, spontaneous contraction of the gallbladder during a study, and contamination with gastric and pancreatic juice are all possible sources of error. In addition, it is necessary to stimulate bile flow to obtain adequate specimens for analysis and the stimuli which can be used are imperfect in several respects. Stimulation by means of intravenous bile salt infusions requires large amounts before a steady state can be reached and is unsuitable for human studies because of side effects at this dose range. Stimulation by food is physiological but contamination of

Fig. 6 Thin-layer chromatogram of bile samples hydrolysed for 18 hours at $110^{\circ} \mathrm{C}$ and developed in a solvent system for deconjugated bile salts (Hofmann, system 1). Samples from two normal subjects, on the left, are compared with two cirrhotic patients, on the right. Note the absence of deoxycholate in the cirrhotic subjects. $D C=$ deoxycholate, $C D C=$ chenodeoxycholate, $L C=$ lithocholate. 
duodenal contents renders analysis difficult and introduces errors in quantitative assays. Secretin was used in the present studies, although it probably stimulates secretion of only that portion of bile produced by the ducts and ductules and not that secreted form parenchymal cells into the cannaliculi (Wheeler, 1965, Forker, 1967). As bile salts are secreted from parenchymal cells secretin should have little effect on bile salt output, and the amounts of bile salt liberated during secretin infusion in the present studies were low, supporting this idea. Stimulation of pancreatic secretion coincidentally with the biliary secretion also complicates interpretation of the test. It does, however, produce sufficient volumes of bile to allow accurate quantitation of the bile salts produced. With good flow of pancreatic juice and bile induced by secretin it was possible to recover a large proportion of that secreted into the duodenum as estimated by recovery of polyethylene glycol. This process was assisted by the use of the 'air-bleed' tube attachment. Spontaneous gallbladder contraction was avoided by promoting a predictable contraction with pancreozymin/cholecystokinin at the onset of the test and at the same time gallbladder function could be assessed.

The changes in volume found in this study in cirrhosis are similar to those described by Gross et al, (1950b) who also noted that patients with cirrhosis produced obviously bile-stained juice in response to secretin as do patients after cholecystectomy (Dreiling, 1950).

While the changes in bile salts described here are clearly related to altered hepatic and biliary function, interpretation of the changes in volume are complicated by the possibility that they could equally arise from the pancreas and liver. Possible explanations are as follows.

If the liver were responsible normally for degradation and inactivation of secretin and if this function were impaired in cirrhosis, then the result of a given dose of injected secretin would be a greater effective stimulus in cirrhosis than in normal subjects where normal breakdown reduces its effect. At doses which exert submaximal effects this would tend to show as an increased volume of bile and pancreatic juice in cirrhosis. Alternatively, the high output may not be due to a high effective secretin dose, but to a change in response of either the biliary tree or the pancreas to secretin. This problem was not resolved in these studies, and, although the first hypothesis is attractive, the second cannot be discounted.

The pattern of bile salt secretion in response to the stimuli applied in this particular test was clearly different in the patients with liver disease. The response to pancreozymin/cholecystokinin was reduced, suggesting that gallbladder function is impaired in cirrhosis, as evidenced by a poor concentrating capacity and a delayed contraction. There is little direct evidence regarding gall- bladder function in cirrhosis, but it is a common clinical experience to be unable to outline the $\Rightarrow$

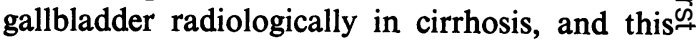
is usually attributed to impaired hepatocellulare function (Cuniff, Dolan, and Leevy, 1953). It $\frac{\overline{\bar{c}}}{\overline{\bar{s}}}$ is possible, however, that it is malfunction of the gallbladder itself which is responsible. The higher concentrations and outputs during theis resting and secretin periods in the cirrhotic $\vec{\circ}$ group resembles that seen in the cholecystecto-mized subjects and suggests that it may be the $\vec{\omega}$ absence or poor function of the gallbladdero which is responsible for higher outputs during stimulation with secretin. One explanation for these higher values may be that as a smalleriv proportion of the bile salt pool is retained in then gallbladder, a greater proportion is left free ino the enterohepatic circulation, and, if the entero-? hepatic pool size is normal, a higher than normal $\vec{T}$ concentration will be present in hepatic bile. $\mathbb{D}$ On this hypothesis the finding of increased? outputs during rest and during stimulation with secretin is seen as a natural consequence of im- $\vec{c}$ paired gallbladder function. Implicit in this suggestion is that the enterohepatic circulation. time for bile salts is shortened in the absence of delay in the gallbladder.

It is interesting that, despite the reducech output of bile salt after gallbladder stimulation the increased output during stimulation with secretin tended to compensate for this so that the total output for the two hours of the test was similar in the control and cirrhotic groups.

Analysis of individual bile salts revealed. definite changes from normal, and similar disturb ances had been noted by Sjövall (1960). Hë showed that in patients with obstructive jaundice and in six patients with cirrhosis, samples of bile obtained from the duodenum contained $a^{3}$ reduced glycine : taurine ratio and a decreased concentration of deoxycholate conjugates as noted in the present investigation. The cause of the changes in glycine : taurine conjugation ratio is unclear, but it has been shown in vitro that liver biopsy specimens from patients with cirrhosis conjugate more cholic acid with glycines than with taurine (Ekdahl, 1958). Similar findings were obtained in obstructive jaundice. The love concentration of deoxycholate conjugates is surprising finding, as this is a secondary bile acid formed from cholate by bacterial activity within the bowel. The low levels suggest that there may be a change in the bacterial flora of the guf in cirrhosis, possibly with a reduced number of dehydrogenating organisms. This effect could be achieved by the oral administration of broad spectrum antibiotics and it is unclear whether this therapy had been given to Sjövall's cirrhoti patients. However, no patient had received. antibiotics in the present study, apart from the two patients who had been given neomycin, and the reduced deoxycholate concentration was not limited to these two subjects. It is possible that 
the bacterial flora was changed in these patients even in the absence of antibiotic therapy. Less likely explanations for the reduced deoxycholate concentration are an impaired absorption of this specific bile acid or a more rapid rehydroxylation of deoxycholate to cholate in the cirrhotic liver. Despite the reduced deoxycholate conjugate output the ratio of trihydroxy:dihydroxy bile salts remained normal, suggesting that there was a relative increase in chenodeoxycholate production or decrease in cholate production. The trihydroxy:dihydroxy ratio of $37: 63$ is similar to the finding of Carey (1958), who noted an increased ratio in the plasma of patients with obstructive jaundice but a ratio of less than 1 in hepatocellular disease. The difference may be due to an impaired hydroxylation mechanism in the more severely impaired parenchyma of the cirrhotic, resulting in a relatively reduced cholate output.

It has been suggested that lithocholic acid may have aetiological significance in cirrhosis (Carey, Wilson, Zaki, and Hanson, 1966), but no evidence of abnormal amounts in the bile was found in these subjects and unconjugated bile salts were not found in excess.

Thus, this analysis of bile salts liberated into the duodenum has revealed a pattern suggestive of gallbladder malfunction, which might explain the frequent failure of cholecystography in cirrhosis (Cuniff et al, 1953) but does not provide an adequate explanation for steatorrhoea in these patients. The total output of bile salt was not diminished for the two-hour test period and the concentration achieved in the duodenum was not less than that found in cholecystectomized subjects who do not appear to have steatorrhoea. Although only three of the cirrhotic patients excreted more than $7.0 \mathrm{~g}$ of fat per day, and only one of these excreted an obviously excessive amount, none of them had a clear-cut deficiency of bile salts. The values for bile salt output and concentration in the single patient excreting $15.3 \mathrm{~g}$ of fat per day were similar to the mean values for the group as a whole.

The stimuli employed in the present study are not entirely physiological and it remains possible that stimulation by food may yield a relatively inadequate bile salt output but this possibility was not tested in the present investigation.

It seems unlikely that a decreased glycine: taurine ratio or a diminished deoxycholate output alone could lead to steatorrhoea.

Consideration of other factors which might produce steatorrhoea has usually been unhelpful. Small intestinal biopsies are usually normal in cirrhosis (Baraona, Orrego, Fernández, Amenabar, Maldonado, Tag, and Salinas, 1962), and, although Gross et al (1950b) found a slightly reduced pancreatic lipase output in such patients, this change was small. No clear explanation for the steatorrhoea has emerged and it may be that several mild abnormalities which individually are not sufficient to give rise to fat malabsorption may do so when combined with each other.

We wish to thank Professor Sheila Sherlock for her kind encouragement and interest throughout this work. We are indebted to Miss Alethea AnthonyMote for her invaluable technical assistance.

\section{References}

Baraona, E., Orrego, H., Fernández, O., Amenabar, E. Maldonado, E., Tag, F., and Salinas, A. (1962). Absorptive function of the small intestine in liver cirrhosis. Amer. J. dig. Dis., 7, 318-330.

Blum, M., and Spritz, N. (1966). The metabolism of intravenously injected isotopic cholic acid in Laennec's cirrhosis. $J$. clin. Invest., 45, 187-193.

Carey, J. B., Jr., (1958). The serum trihydroxy-dihydroxy bile acid ratio in liver and biliary tract disease. J. clin. Invest., 37, 1494-1503.

Carey, J. B., Jr. Wilson, I. D., Zaki, F. G., and Hanson, R. F (1966). The metabolism of bile acids with special reference to liver injury. Medicine (Baltimore), 45, 461-470.

Cuniff, C. L., Dolan, M. A., and Leevy, C. M. (1953). Cholecystography in portal cirrhosis without jaundice. Gastroenterology, 25, 557-564.

Dreiling, D. A. (1950). Studies of pancreatic function. III. The use of the secretin test in the diagnosis of patients with the post-cholecystectomy syndrome. Gastroenterology, 16, 162-171.

Ekdahl, H. (1958). On the conjugation and formation of bile acids in the human liver. VI. On the conjugation of cholic acid-2414-C in human liver homogenates in various diseases with special reference to patients with jaundice. Acta chir. scand., 115, 208-226.

Forker, E. L. (1967). Two sites of bile formation as determined by mannitol and erythritol clearance in the guinea pig. J. clin. Invest., 46, 1189-1195.

Gross, J. B., Comfort, M. W., Wollaeger, E. E., and Power, M. H. $(1950$ a). Total solids, fat and nitrogen in the fæces. V. A study of patients with primary parenchymatous hepatic disease. Gastroenterology, 16, 140-150.

Gross, J. B., Comfort, M. W., Wollaeger, E. E., and Power, M. H. (1950b). External pancreatic function in primary parenchymatous hepatic disease as measured by analysis of duodenal contents before and after stimulation with secretin. Gastroenterology, 16, 151-161.

Hofmann, A. F. (1962). Thin-layer adsorption chromatography of free and conjugated bile acids on silicic acid. J. Lipid Res., 3, 127-128.

Hyden, S. (1956). A turbidometric method for the determination of higher polyethylene glycols in biological materials. K. Lantbr Högsk. Annlr, 22, 139-145.

Iwata, T., and Yamasaki, K. (1964). Enzymatic determination and thin-layer chromatography of bile acids in blood. J. Biochem. (Tokyo), 56, 424-431.

van de Kamer, J. H., ten Bokkel Huinink, H., and Weyers, H. A. (1949). A rapid method for the determination of fat in feces. J. biol. Chem., 177, 347-355.

Sandberg, D. H., Sjövall, J., Sjövall, K., and Turner, D. A. (1965). Measurement of human serum bile acids by gas-liquid chromatography. J. Lipid. Res., 6, 182-192.

Sjovall, J. (1960). Bile acids in man under normal and pathological conditions. Bile acids and steroids 73. Clin. chim. Acta, 5, 33-41.

Turnberg, L. A., and Anthony-Mote, A. (1969). The quantitative determination of bile salts in bile using thin-layer chromatography and $3 a$-hydroxysteroid dehydrogenase. Clin. chim. Acta, 24, 253-259.

Wheeler, H. O. (1965). Inorganic ions in bile. In The Biliary System: A Symposium of the NATO Advanced Study Institute, edited by W. Tavlor, pp. 481-493. Blackwell, Oxford. 